\title{
Oxygen Reduction on Glassy Carbon-Supported PdAu Nanoparticles in Perchloric Acid Solution
}

\author{
Jelena Golubović ${ }^{1}$, Irina Srejić ${ }^{2}$, Svetlana Štrbac ${ }^{1, *}$ \\ ${ }^{1}$ ICTM-Department of Electrochemistry, University of Belgrade, Njegoševa 12, 11000 Belgrade, \\ Serbia \\ 2 INS Vinča, Laboratory of Atomic Physics, University of Belgrade, Mike Alasa 12-14, 11001 \\ Belgrade, Serbia \\ *E-mail: sstrbac@tmf.bg.ac.rs
}

doi: $10.20964 / 2021.08 .01$

Received: 6 April 2021 / Accepted: 27 May 2021 / Published: 30 June 2021

\begin{abstract}
$\mathrm{PdAu} / \mathrm{GC}$ nanoparticles obtained by the electrochemical deposition of gold followed by the spontaneous palladium deposition show a remarkable catalytic activity for the oxygen reduction reaction (ORR) in perchloric acid solution. AFM images reveal the size, shape, and coverage of the GC electrode with Au and PdAu nanoislands. Au/GC electrode with the full GC coverage by the deposited gold islands and activated by potential cycling shows the highest ORR activity. The initial potential for ORR shifts positively for $200 \mathrm{mV}$ compared to polycrystalline gold. With the addition of palladium, the activity for ORR enhances significantly. For the most active PdAu/GC electrode, the initial potential shifts positively for another $250 \mathrm{mV}$, which coincides with polycrystalline palladium.
\end{abstract}

Keywords: Gold, palladium, glassy carbon, oxygen reduction, acid solution

\section{FULL TEXT}

(C) 2021 The Authors. Published by ESG (www.electrochemsci.org). This article is an open access article distributed under the terms and conditions of the Creative Commons Attribution license (http://creativecommons.org/licenses/by/4.0/). 